\title{
Evaluation of clinical and reproductive parameters in Mangalarga Marchador mares treated with different doses of Cloprostenol or Dinoprost
}

\author{
[Avaliação de parâmetros clínicos e reprodutivos de éguas Mangalarga Marchador tratadas com \\ diferentes doses de Cloprostenol e Dinoprost]
}

\section{"Artigo Científico/Scientific Article"}

\author{
José Carlos Ferreira-Silva ${ }^{1 *}$, Pábola Santos Nascimento ${ }^{1}$, Marlon Vasconcelos Azevedo ${ }^{2}$, \\ Jorge Motta Rocha ${ }^{3}$, Heder Nunes Ferreira ${ }^{4}$, Marcelo Tigre Moura ${ }^{1}$, \\ Claudio Coutinho Bartolomeu ${ }^{1}$, Marcos Antonio Lemos Oliveira ${ }^{1}$
}

\begin{abstract}
${ }^{1}$ Laboratorio de Biotécnicas Reprodutivas, Universidade Federal Rural de Pernambuco, Recife-PE, Brasil.
${ }^{2}$ Equestre Clínica, Cirurgia e Reprodução Animal, Campina Grande-PB, Brasil.

${ }^{3}$ Universidade Federal do Rio Grande do Norte, Natal-RN, Brasil.

${ }^{4}$ Faculdade Pio Décimo - Hospital Veterinário, Aracaju-SE, Brasil.

*Autor para correspondência/Corresponding author: E-mail: ferreirasilva.jc@ gmail.com
\end{abstract}

\begin{abstract}
The work evaluated the activity of reduced and conventional doses of luteolytic substances on both clinical and reproductive parameters of mares. Females received intramuscularly, $125 \mu \mathrm{g}(\mathrm{n}=20)$ and $250 \mu \mathrm{g}(\mathrm{n}=20)$ of Cloprostenol or $2.5 \mathrm{mg}(\mathrm{n}=20)$ and $5.0 \mathrm{mg}(\mathrm{n}=20)$ of Dinoprost. The rectal temperature and both heart and respiratory frequencies were assessed before and after administration of such luteolytics, considering the occurrence of sweating, diarrhea, colic, and prostration. Estrus detection and follicular development were monitored daily until ovulation, when artificial insemination (AI) was performed. Pregnancy was diagnosed on day 30 and confirmed on day 60. Only mares treated with 2.5 and $5.0 \mathrm{mg}$ of Dinoprost showed alterations $(\mathrm{P}<0.05)$ of respiratory frequency, while the remaining parameters were not altered $(\mathrm{P}>0.05)$. The sweating occurred in 5\% and $10 \%$ of treated mares, respectively, with $2.5 \mathrm{mg}$ and $5.0 \mathrm{mg}$ of Dinoprost and diarrhea in only $5 \%$ of those that received $5.0 \mathrm{mg}$ of this luteolytic. Both estrus and pregnancy rates in treated mares with $125 \mu \mathrm{g}$ of Cloprostenol (45\%/35\%) and $2.5 \mathrm{mg}$ of Dinoprost $(50 \% / 30 \%)$ were lower than $(\mathrm{P}<0.05)$ those that received $250 \mu \mathrm{g}$ of Cloprostenol (85\%/70\%) and $5 \mathrm{mg}$ of Dinoprost $(90 \% / 75 \%)$. Both estrus and pregnancy rates in control mares were lower $(\mathrm{P}<0.05)$ than their treated counterparts. In conclusion, although not promoting significant clinical alterations, reduced doses of luteolytics did not display the same efficiency of conventional doses to induce estrus in mares.
\end{abstract}

Keywords: equine; prostaglandin; side effect; estrus.

\section{Resumo}

Avaliou-se a ação de doses reduzidas e convencionais de substâncias luteolíticas sobre parâmetros clínicos e reprodutivos de éguas. As femeas receberam intramuscularmente, $125 \mu \mathrm{g}(\mathrm{n}=20)$ e $250 \mu \mathrm{g}(\mathrm{n}=20)$ de Cloprostenol e $2.5 \mathrm{mg}(\mathrm{n}=20)$ e $5.0 \mathrm{mg}(\mathrm{n}=20)$ de Dinoprost. A temperatura retal e as frequências cardíaca e respiratória foram aferidas antes e após a administração desses luteolíticos, considerando-se ainda a ocorrência de sudorese, diarreia, cólica e prostração. Monitorou-se o estro e o desenvolvimento folicular até a ovulação, quando realizou-se a inseminção artificial. A gestação foi diagnosticada com 300 e confirmada no $60 \mathrm{o}$ dia. Apenas as éguas tratadas com 2,5 e $5,0 \mathrm{mg}$ de Dinoprost apresentaram alteração $(\mathrm{P}<0.05)$ da frequência respiratória e os demais parâmetros não foram alterados $(\mathrm{P}>0.05)$. A sudorese ocorreu em $5 \% \mathrm{e}$ $10 \%$ das éguas tratadas, respectivamente, com $2.5 \mathrm{mg}$ e $5.0 \mathrm{mg}$ de Dinoprost e a diarréia em apenas $5 \%$ daquelas que receberam $5.0 \mathrm{mg}$ desse luteolítico. As porcentagens de estro e prenhez das éguas tratadas com $125 \mu \mathrm{g}$ de Cloprostenol $(45 \% / 35 \%)$ e $2.5 \mathrm{mg}$ de Dinoprost $(50 \% / 30 \%)$ foram menores $(\mathrm{P}<0.05)$ do que os daquelas que receberam $250 \mu \mathrm{g}$ de Cloprostenol (85\%/70\%) e $5 \mathrm{mg}$ de Dinoprost (90\%/75\%). O estro e a prenhez das éguas Controle foram menores $(\mathrm{P}<0.05)$ do que nas tratadas. Conclui-se que apesar de não promoverem alterações significativas dos parâmetros clínicos, as doses reduzidas não apresentam as mesmas eficiências dos tratamentos com doses convencionais para induzir o estro.

Palavras-Chave: equino; prostaglandina; efeito colateral; estro. 


\section{Introdução}

Prostaglandins are long chain fatty acids that play similar roles to hormones in several tissues during both physiological and pathological processes (Smith and Manson, 1974; Coffman and Pinto, 2016). In reproduction, these substances are normally used to induce luteolysis (Newcombe et al., 2008) and uterine contractions, in order to induce delivery or pregnancy loss (Noden et al., 1978; Ousey et al., 1984; Brendemuehl, 2002; Ladim Alvarenga et al., 2006).

Prostaglandins can be used on clinical approaches to endometritis treatment (Faria and Gradela, 2010) and mostly in assisted reproduction programs, such as artificial insemination (AI) and embryo transfer (ET), that require perfect synchrony of estrus and ovulation between donor and recipient mares (Taveiros et al., 2003/2008; Rabelo et al., 2009). In general, the response to treatment with luteolytic agents is conditioned to the phase of the estrous cycle (Azevedo et al., 2014/2015).

Although the results described in horses remain conflicting, this treatment should be performed within days 5 and 16 post-ovulation (Squires, 2008). The usage of luteolytic agents before day 7 post-ovulation, may result in the development of hemorrhagic and anovulatory follicles in the following estrous cycles, compromising the fertility of the mare (Ginther et al., 2007/2008; Cuervo-Arango and Newcombe, 2009/2010; Leal Fonseca et al., 2016).

Prostaglandins may also promote side effects in other systems, thus inducing alterations in thermoregulation, sweating, tachycardia, abdominal distress, motor incoordination, prostration and, in extreme cases, anaphylaxis and chemotaxis (Allen et al., 1974; Miller et al., 1976; Nelson, 1976; Goyings et al., 1977; Faria and Gradela, 2010; Kuhl et al., 2016ab). Alternatively, the development of prostaglandin synthetic analogs with increased biological activity and greater specificity toward the reproductive tract has led to lower side effects (Cuervo-Arango and Newcombe, 2012; Kuhl et al., 2016ab).

In order to minimize such side effects, the evaluation of physiological parameters, possibly influenced by prostaglandins and its synthetic analogs, continues as an up-to-date research topic and important to be taken into account (Evans et al., 2007; Silva et al., 2015), specially in the Northeast of Brazil, where limited information is available about the subject. Under such conditions, the work was aimed to evaluate the effect of reduced doses of Cloprostenol or Dinoprost on the heart rate, respiratory rate, and rectal temperature, while monitoring for sweating, diarrhea, colic, and prostration, but also the estrus induction efficiency and pregnancy thereafter.

\section{Material and Methods}

The experiment was conducted in Limoeiro, Pernambuco State, Brazil. The farm is in a region of tropical sub-humid weather and is located following the geographic coordinates $7^{\circ} 52$ ' $29^{\prime}$ ' $\mathrm{S}$ latitude and $35^{\circ} 27^{\prime} 01$ ' $\mathrm{W}$ longitude. The mean annual temperature is $24{ }^{\circ} \mathrm{C}$ and mean rainfall of $1,248 \mathrm{~mm}^{3}$.

Donor and recipient mares were nonlactating and of the Mangalarga Machador breed, with age from 5 to 15 years and live weight from 450 to $550 \mathrm{Kg}$. Mares were subject to semiextensive management practices and maintained in cultivated pastures (Digitaria decumbes) and access to water and mineralized salt (Suprafós 73, Supranor $^{\circledR}$ ) ad libitum. Moreover, mares were also supplemented with Tifton (Cynodon spp), Alfalfa (Medicago sativa), and $4 \mathrm{~kg}$ of commercial horse food (Corcelina ${ }^{\circledR}$, Purina).

Mare selection was performed by body condition score that varied from 5 to 7 in an 1 to 9 scale, according to Henneke et al. (1983) and cyclicity condition. The selection also considered the analysis of reproductive performance and both clinical and gynecological examinations. The later was performed using ultrassound (Aquila Pro Esaote) equipped with a linear multi frequential linear transducer ( 6 and $8 \mathrm{MHz}$ ) in order to identify the presence of uterine fluid and endometrial alterations that may affect fertility, as suggested by Taveiros et al. (2008).

Mares were used in the experiment when found in the diestrous phase, between days 8 and 10 post-ovulation were treated with different doses of luteolytic agents by an intramuscular (IM) shot. A group of mares $(n=40)$ received D-Cloprostenol (Ciosin ${ }^{\circledR}$, MSD Saúde Animal) in $125 \mu \mathrm{g}(\mathrm{n}=20)$ and $250 \mu \mathrm{g}(\mathrm{n}=20)$ doses. Alternatively, mares ( $\mathrm{n}$ $=40$ ) were subject to Dinoprost Tromethamine (Lutalyse $^{\circledR}$, Pfizer) treatment with $2.5 \mathrm{mg}(\mathrm{n}=20)$ or $5.0 \mathrm{mg}(\mathrm{n}=20)$ doses. Mares of the Control group $(\mathrm{n}=20)$ were subject to an $2 \mathrm{~mL}$ saline solution (Soro Fisiológico, Farmace ${ }^{\circledR}$ ) dose, also by an IM shot. 
After treatment with these luteolytic agents, mares were scored for rectal temperature $\left({ }^{\circ} \mathrm{C}\right)$ and both heart (bpm) and respiratory (mpm) frequencies as described by Silva et al. (2015), five minutes before and fifteen minutes after the administration of the luteolytic agent. Mares were also monitored for sweating within inital 60 minutes after treatment, and also for diarrhea, colic, and prostration up to 24 hours post-administration of the luteolytic agent. During the evaluation of these later clinical parameters, data was collected as present or absent.

Mares were also observed daily for estrus detection. The estrus was scored as induced those that were observed within initial five days (120 hours) post-administration of the luteolytic agent. After estrus detection, follicular development was monitored by ultrasonography at 12 -hour intervals until ovulation.

After detection of ovulation, AI was performed using freshly collected semen with a dose of $500 \times 10^{6}$ sperm cells from stallions of proven fertility. Pregnancy diagnosis was performed by rectal palpation accompanied by ultrasonography on day 30 and later confirmed on day 60 post-AI.

The data was initially subject to the ShapiroWilks normality test. The data with normal distribution was further subject to ANOVA for comparisons among groups, while paired $\mathrm{T}$ test was used for comparisons between time-points inside groups. The binomial data was scored as percentages and inferred by the chi-square test with the Yates correction factor (Preacher, 2001).
The significance level was 5\% for all analysis.

\section{Results}

Table 1 displays the clinical findings concerning the presence or absence of sweating, diarrhea, colic, and prostration in mares treated with luteolytic agents. Only mares treated with Dinoprost showed increased sweating during initial 20 minutes after treatment, while 5\% (1/20) were those from $2.5 \mathrm{mg}$ dose and $10 \%$ (2/20) of mares treated with $5.0 \mathrm{mg}$ of Dinoprost. Diarrhea was found in $5 \%(1 / 20)$ mares treated with $5.0 \mathrm{mg}$ of this luteolytic agent.

Table 2 holds the mean values for rectal temperature, heart frequency, and respiratory frequency obtained before (5 minutes) and after (15 minutes) treatment with Cloprostenol and Dinoprost, under both reduced and conventional doses. Only mares treated with 2.5 or $5.0 \mathrm{mg}$ Dinoprost doses showed alterations $(\mathrm{P}<0.05)$ of respiratory frequency. The other parameters were not influenced $(P>0.05)$ by such treatments.

Figure 1 shows that reduced doses of both Cloprostenol and Dinoprost were less efficient $(\mathrm{P}<$ $0.05)$ than conventional doses to induce estrus (respectively, 9/20 and 10/20; 17/20 and 18/20), was more efficient $(\mathrm{P}<0.05)$ than obtained in control mares (3/20). Similarly, pregnancy rates in mares treated with reduced doses (respectively, $7 / 20$ and 6/20) was lower $(\mathrm{P}<0.05)$ than those in mares that received conventional doses (respectively, 14/20 and 15/20) and was not more efficient $(\mathrm{P}>0.05)$ than the pregnancy rate obtained in control mares $(2 / 20)$.

Table 1. Clinical findings related to sweating, diarrhea, colic, and prostration within initial 24 hours in mares treated with Cloprostenol and Dinoprost.

\begin{tabular}{ccccc}
\hline \multirow{2}{*}{ Group } & \multicolumn{3}{c}{ Clinical Findings } \\
\cline { 2 - 5 } & Sweating & Diarrhea & Colic & Prostration \\
\hline Cloprostenol 125 & Absent & Absent & Absent & Absent \\
Cloprostenol 250 & Absent & Absent & Absent & Absent \\
Dinoprost 2.5 & Present & Absent & Absent & Absent \\
Dinoprost 5.0 & Present & Present & Absent & Absent \\
Control & Absent & Absent & Absent & Absent \\
\hline
\end{tabular}


Table 2. Mean and standard deviation $\left(\bar{x}_{ \pm}\right.$SD) for rectal temperature, heart and respiratory frequencies in Manga Larga Marchador mares before ( 5 minutes) and after (15 minutes) treatment with different doses of Cloprostenol ( $\mu \mathrm{g})$ or Dinoprost (mg).

\begin{tabular}{|c|c|c|c|c|c|c|}
\hline \multirow{4}{*}{ Group } & \multicolumn{6}{|c|}{ Physiological Parameters } \\
\hline & \multicolumn{2}{|c|}{$\begin{array}{l}\text { Rectal Temperature } \\
\left({ }^{0} \mathrm{C}\right)\end{array}$} & \multicolumn{2}{|c|}{$\begin{array}{l}\text { Heart Frequency } \\
\text { (bpm) }\end{array}$} & \multicolumn{2}{|c|}{$\begin{array}{c}\text { Respiratory Frequency } \\
(\text { (mrm) }\end{array}$} \\
\hline & Before & After & Before & After & Before & After \\
\hline & $\bar{x}_{ \pm \mathrm{SD}}$ & $\bar{x}_{ \pm \mathrm{SD}}$ & $\bar{x}_{ \pm \mathrm{SD}}$ & $\bar{x}_{ \pm \mathrm{SD}}$ & $\bar{x}_{ \pm \mathrm{SD}}$ & $\bar{x}_{ \pm \mathrm{SD}}$ \\
\hline Cloprostenol 125 & $38.4 \pm 0.2$ & $38.4 \pm 0.2$ & $49.9 \pm 6.6$ & $51,7 \pm 5.5$ & $27.4 \pm 2.9$ & $27.8 \pm 2.5$ \\
\hline Cloprostenol 250 & $38.4 \pm .0 .2$ & $38.4 \pm 0.2$ & $51.6 \pm 4.5$ & $52,0 \pm 3.9$ & $27.3 \pm 2.5$ & $28.1 \pm 2,6$ \\
\hline Dinoprost 2.5 & $38.3 \pm 0.20$ & $38.3 \pm 0.2$ & $53.8 \pm 5.2$ & $53.6 \pm 4.8$ & $26.8 \pm 2.6^{\mathrm{a}}$ & $29.2 \pm 2.7^{\mathbf{b}}$ \\
\hline Dinoprost 5.0 & $38.4 \pm 0.2$ & $38.4 \pm 0.2$ & $51.3 \pm 4.8$ & $52.2 \pm 4.8$ & $27.5 \pm 1.9^{\mathrm{a}}$ & $29.6 \pm 2.1^{b}$ \\
\hline Control & $38,4 \pm 0,2$ & $38.4 \pm 0.2$ & $49.8 \pm 6,6$ & $50.4 \pm 8.0$ & $27.1 \pm 2.9$ & $27.8 \pm 2.5$ \\
\hline
\end{tabular}

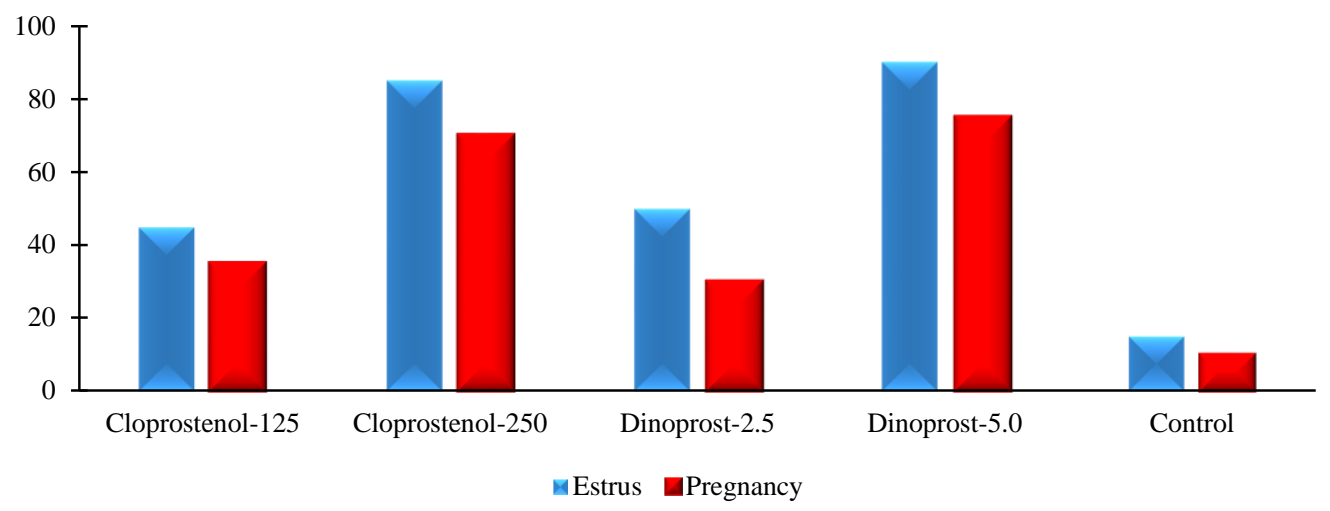

Figure 1. Estrus and pregnancy rates in Manga Larga Marchador mares subject to reduced and convetional doses of Cloprostenol $(\mu \mathrm{g})$ and Dinoprost $(\mathrm{mg})$ treatments. Different letters, uppercase (estrus) or lowercase (pregnancy), indicate statistical difference $(\mathrm{P}<0.05)$ among groups.

\section{Discussion}

The side effects occur after administration of conventional doses of luteolytic agents in $10 \%$ to $40 \%$ of mares treated with prostaglandin, thus being commonly observed sweating, diarrhea, tachycardia, and colic-resembling signs (Miller et al.; 1976; Irvine et al., 2002; Faria and Gradela, 2010; Coffman and Pinto, 2016). In this study, sweating was triggered by Dinoprost treatment, irrespectively of the dose used. This clinical alteration was expected with the conventional dose, but not with the reduced one, since both the manufacturer and some authors highlight about this possibility (Miller et al.; 1976; Irvine et al., 2002; Faria and Gradela, 2010; Coffman and Pinto, 2016).

The sweating can be due to cutaneous vasodilatation induced by prostaglandins, as demonstrated both in humans (McCord et al., 2006) and animals (Faria and Gradela, 2010; Coffman and Pinto, 2016; Kuhl et al., 2016ab/2017). In horses, this clinical sign is due to adrenoreceptor stimulation of sudoriparous gland cells, determined by a significant increase in adrenalin and noradrenalin concentrations after prostaglandin administration (Jenkinson et al., 2006/2007). In general, sweating gradually increases due to increasing doses (Miller et al., 1976; Irvine et al., 2002; Kuhl et al., 2016ab). Mares treated with Cloprostenol did not display sweating, a fact that was expected due to its greater specificity over the reproductive tract, that ultimately leads to reduced side effects (CuervoArango and Newcombe, 2012; Kuhl et al., 2016ab/2017). 
As described above, the percentage of mares displaying sweating was low in comparison to results described by other authors (Faria and Gadelha, 2010; Coffman and Pinto, 2016). This finding can be attributed to the location where the experiment was conducted, under tropical subhumid conditions and mild mean annual temperature. According to Kuhl et al. (2016a), excessive sweating is more perceptible in mares subject to warm and humid environments, where air humidity saturation occurs more easily, even using prostaglandin analogs.

Some mares in this study showed diarrhea after treatment with the conventional dose of Dinoprost. This clinical sign, according to Alcántara et al. (2005) and Kuhl et al. (2016a), occurs in a high percentage of mares treated with the natural form of the prostaglandin or even with some synthetic analogs, irrespectively of the dose used. The effect of prostaglandins on fecal consistency was also reported in humans and may be caused by direct stimulation of intestinal smooth muscle (Horton and Main, 1963; Horton et al., 1968). According to Kuhl et al. (2016ab), an indirect and alternative effect of prostaglandins on the gastrointestinal function that should be taken into account is the release of cortisol. In this study, no clinical sign was observed that could be suggestive of any abdominal pain or colic development. However, according to Coffman and Pinto (2016), prostaglandin administration may cause hipergastromotility, while some mares may display colic or colic-like symptoms.

The rectal temperature was not affected by different doses administered and neither due to the luteolytic agent used since Dinoprost and Cloprostenol did not exert any influence on the rectal temperature. Contrary to these findings, Kuhl et al. (2016ab) found a significant decrease in rectal temperature after administration of prostaglandin synthetic analogs. Miller et al. (1976) describes this phenomenon as a response to sweating and must be interpreted as a thermoregulation mechanism. Since sweating was rather discreet and in few mares, as described above, this effect may not have reached a magnitude to affect the rectal temperature.

Although some authors found an increase in heart frequency, in a dose-dependent manner (Miller et al., 1976; Nie et al., 2001; Irvine et al., 2002), the absence of heart frequency alterations in response to Cloprostenol and Dinoprost administrations, as described above, are in agreement with findings by Alcántara et al. (2005). In contrast, the respiratory frequency was altered by both doses of Dinoprost, in agreement with Nie et al. (2001) who found similar alterations with treatment with both Dinoprost and Cloprostenol. A possible explanation for this fact described above is that prostaglandin acts a bronchoconstrictor factor (Kirschvink et al., 2001), thus lowering the respiratory capacity of the animal and leading to increases in the respiratory frequency as a compensation mechanism.

The estrus induction by both luteolytic agents was considered very promising since most mares responded to treatment within a period of five days, especially with conventional doses. This result was initially credited to the fact that mares displayed normal cyclicity before the experiment and thereafter due to the fact that, at the time-point of treatment with luteolytic agents, mares were in the diestrous phase. Therefore, mares were found in the receptive period for the activity of luteolytic agents, as previously reported by Weber et al. (2001), Kotwica et al. (2002), and Kuhl et al. (2016ab).

The body condition score, the cyclicality status, and known reproductive performance may have contributed to pregnancy in mares with induced estrus, which were similar to those found by Cuervo-Arango and Newcombe (2010), Metcalf and Thompson (2010), and Leal Fonseca et al. (2016). Moreover, it is an interesting fact to outline that the number satisfactory of pregnant mares may have also been due to follicular growth control that allowed the AI to be performed immediately after ovulation. It is also important to consider that the number of pregnant mares during this five-day period was greater than those from the control, a fact that eases management practices and further minimizes production costs with trained personnel.

\section{Conclusion}

The results allow the conclusion that, although not promoting significant clinical alterations, reduced doses of luteolytic agents did not display the same efficiency of conventional doses to induce estrus in mares.

\section{Conflict of Interest}

The authors would like to declare no conflict of interest in the study. 


\section{Animal Welfare}

The research was approved by the Ethics Commitee for Animal Research at Universidade Federal Rural de Pernambuco (License: 011/2013).

\section{Acknowledments}

Authors would like to acknowledge the Coordenação de Aperfeiçoamento de Pessoal de Nível Superior (JCFS, MTM) and Fundação de Amparo à Ciência e Tecnologia do Estado de Pernambuco (PSN) for fellowship support during the study.

\section{Referências}

Alcántara, B.; Boeta, M.; Porras, A. Luteolysis, estrus induction, and clinical side effects in mares treated with a PDF2 $\alpha$ analog, cloprostenol (Sinocrel 11-21). Journal of Equine Veterinary Science, 25(9), 384-386, 2005.

Allen, W.R.; Stewart, F.; Cooper, M.J.; Crowhurst, R.C.; Simpson, D.J.; McEnery, R.J.; Greenwood, R.E.S.; Rossdale, P.D.; Ricketts, S.W. Further studies on the use of synthetic prostaglandin analogues for inducing luteolysis in mares. Equine Veterinary Journal, 6(1): 31-35, 1974.

Azevedo, M.V.; Souza, N.M.; Ferreira-Silva, J.C.; Batista, I.O.; Moura, M.T.; Oliveira, M.A.; Oliveira, M.A.L.; Lima, P.F. Induction of multiple ovulations in mares using low doses of GnRH agonist Deslorelin Acetate at 48 hours after luteolysis. Pferdeheilkunde, 31: 160-164, 2015.

Azevedo, M.V.; Souza, N.M.; Ferreira-Silva, J.C.; Batista, I.O.; Sales, F.A.B.M.; Alvarenga, M.A.; Oliveira, M.A.L.; Lima, P.F. Indução de ovulações duplas utilizando baixa dose de deslorelina em éguas. Ciência Veterinária no Trópicos, 17 (1/2): 42-47, 2014.

Brendemuehl, J.P. Effects of oxytocin and cloprostenol on luteal formation, function and pregnancy rates in mares. Theriogenology, 58: 623-626, 2002.

Coffman, E.A.; Pinto, C.R. A Review on the Use of Prostaglandin F $2 \alpha$ for Controlling the Estrous Cycle in Mares. Journal of Equine Veterinary Science, 40: 34-40, 2016.

Cuervo- Arango, J.; Newcombe, J.R. Relationship between dose of cloprostenol and age of corpus luteum on the luteolytic response of early dioestrous mares: a field study.
Reproduction in Domestic Animals, 47(4): 660-665, 2012.

Cuervo- Arango, J.; Newcombe, J.R. Cloprostenol in equine reproductive practice: something more than a luteolytic drug. Reproduction in Domestic Animals, 45(5): 1262-1267, 2010.

Cuervo-Arango, J.; Newcombe, J.R. The effect of hormone treatments (hCG and cloprostenol) and season on the incidence of hemorrhagic anovulatory follicles in the mare: a field study. Theriogenology, 72(9): 1262-1267, 2009.

Evans, D.L. Physiology of equine performance and associated tests of function. Equine Veterinary Journal, 39(4): 373-383, 2007.

Faria, D.R; Gradela, A. Hormonioterapia aplicada à ginecologia equina. Revista Brasileira de Reprodução Animal, 34(2): 114-22, 2010.

Ginther, O.J.; Gastal, M.O.; Gastal, E.L.; Jacob, J.C.; Beg, M.A. Induction of haemorrhagic anovulatory follicles in mares. Reproduction, Fertility and Development, 20(8): 947-954, 2008 .

Ginther, O.J.; Gastal, E.L.; Gastal, M.O.; Beg, M.A. Incidence, endocrinology, vascularity, and morphology of hemorrhagic anovulatory follicles in mares. Journal of Equine Veterinary Science, 27(3): 130-139, 2007.

Goyings, L.S.; Lauderdale, J.W.; McConnell, R.F. Pharmacologic and toxicologic study of prostaglandin F2alpha in mares. American Journal of Veterinary Research, 38(9): 1445, 1977.

Henneke, D.R.; Potter, G.D.; Kreider, J.L.; Yeates, B.F. Relationship between condition score, physical measurements and body fat percentage in mares. Equine Veterinary Journal, 15(4): 371-372, 1983.

Horton, E.W.; Main, I.H.; Thompson, C.J.; Wright, P.M. Effect of orally administered prostaglandin E1 on gastric secretion and gastrointestinal motility in man. Gut, 9(6): 655, 1968.

Horton, E.W.; Main, I.H.M. A comparison of the biological activities of four prostaglandins. British Journal of Pharmacology, 21(1): 182-189, 1963.

Irvine, C.H.G; McKEOUGH, V.L.; Turner, J.E.; Alexander, S.L.; Taylor, T.B. Effectiveness of a two- dose regimen of prostaglandin administration in inducing luteolysis without adverse side effects in mares. Equine Veterinary Journal, 34(2): 191-194, 2002. 
Jenkinson, D.M.; Elder, H.Y.; Bovell, D.L. Equine sweating and anhidrosis Part 2: anhidrosis. Veterinary Dermatology, 18(1): 2-11, 2007.

Jenkinson, D.M.; Elder, H.Y.; Bovell, D.L. Equine sweating and anhidrosis Part 1-equine sweating. Veterinary Dermatology, 17(6): 361-392, 2006

Kirschvink, N.; Bureau, F.; Art, T.; Lekeux, P. Bronchoconstrictive properties of inhaled 8epi-PGF $2 \alpha$ in healthy and heaves-susceptible horses. Veterinary Research, 32(5): 397407, 2001.

Kotwica, J.; Bogacki, M.; Rekawiecki, R. Neural regulation of the bovine corpus luteum. Domestic Animal Endocrinology, 23(1): 299-308, 2002.

Kuhl, J.; Aurich, J.; Aurich, C. Effects of the prostaglandin $\mathrm{F} 2 \alpha$ analogues cloprostenol and luprostiol in combination with hCG on synchronisation of oestrus and ovulation in mares. Journal of Equine Veterinary Science, 57: 67-70, 2017.

Kuhl, J.; Aurich, J.E.; Aurich, C. Efficiency of two prostaglandin F2 $\alpha$ analogs for synchronization of estrus and ovulation in mares. Journal of Equine Veterinary Science, 41: 56-57, 2016.

Kuhl, J.; Nagel, C.; Ille, N.; Aurich, J.E.; Aurich, C. The PGF $2 \alpha$ agonists luprostiol and dcloprostenol reliably induce luteolysis in luteal phase mares without evoking clinical side effects or a stress response. Animal Reproduction Science, 168: 92-99, 2016.

Landim-Alvarenga, F.C.; Prestes, N.C.; Fernandes, C.B.; Interrupção da gestação e indução de parto. In: LandimAlvarenga FC, Prestes NC, Fernandes CB (Org.). Obstetrícia veterinária. Rio de Janeiro: Guanabara Koogan, 2006. 272p.

Leal Fonseca, F.C.V.; Jacob, J.C.F.; André, M.; Sá, F.; Dutra, G.A.; Guerson, Y.B.; Jesus, V.L.T. Efeito do uso de dinoprost trometamina sobre a taxa de gestação em éguas Mangalarga Marchador. Revista Brasileira de Medicina Veterinária, 38(Supl.2):164-168, 2016.

McCord, G.R.; Cracowski, J.L.; Minson, C.T. Prostanoids contribute to cutaneous active vasodilation in humans. American Journal of Physiology-Regulatory, Integrative and Comparative Physiology, 291(3): 596-602, 2006.

Metcalf, E.S., Thompson, M.M. The effect of PGF2 $\alpha$-induction of estrus on pregnancy rates in mares. Journal of Equine Veterinary Science, 30(4): 196-199, 2010.

Miller, P.A.; Lauderdale, J.W.; Geng, S. Effects of various doses of Prostin F2 alpha ${ }^{\circledR}$ on estrous cycles, rectal temperature, sweating, heart rate and respiration rate in mares. Journal of Animal Science, 42(4): 901-911, 1976.

Nelson, A.M.R. The Therapeutic Activity, PostTreatment Fertility and Safety of Prostaglandin F2 $\alpha$ - Tham Salt in Clinically Anoestrous Mares: A Review. Equine Veterinary Journal, 8(2): 75-77, 1976.

Newcombe, J.R.; Jöchle, W.; Cuervo-Arango, J. Effect of dose of cloprostenol on the interval to ovulation in the diestrous mare: a retrospective study. Journal of Equine Veterinary Science, 28(9): 532-539, 2008.

Nie, G.J.; Goodin, A.N.; Braden, T.D.; Wenzel, J.G. Luteal and clinical response following administration of dinoprost tromethamine or cloprostenol at standard intramuscular sites or at the lumbosacral acupuncture point in mares. American Journal of Veterinary Research, 62(8): 1285-1289, 2001.

Noden, P.A.; Oxender, W.D.; Hafs, H.D. Early Chances in Serum Progesterone, Estradiol and LH during Prostaglandi F2 $\alpha$-induced Luteolysis in Mares. Journal of Animal Science, 47(3): 666-671, 1978.

Ousey, J.C.; Dudan, F.; Rossdale, P.D. Preliminary studies of mammary secretions in the mare to assess foetal readiness for birth. Equine Veterinary Journal, 16(4): 259-263, 1984

Preacher, K.J. Calculation for the chi-square test: An interactive calculation tool for chi-square tests of goodness of fit and independence [software], 2001. Available from http://quantpsy.org. Acesso no dia 12.04.17.

Rabelo, M.C.; Taveiros, A.W.; Melo, P.R.M.; Chaves, R.M.; Santos Junior, E.R.; Aguiar Filho, C.R.; Bezerra, F.Q.G.; Almeida-Irmão, J.M.; Freitas Neto, L.M.; Lima, P.F.; Oliveira, M.A.L. Taxas de prenhez e de perda embrionária em éguas da raça Mangalarga Marchador em diferentes status reprodutivos utilizadas como receptoras em programas de transferência de embriões. Medicina Veterinária (UFRPE), 3(4): 13-19, 2009.

Silva, M.C.; Berkman, C.; Badial, P.R.; Sarmento, E.B.; Oliveira, N.F.; Raphael, U.B.; Medeiros, J.M.Q.; Teixeira， L.G. Determinação das variáveis fisiológicas e bioquímicas de equinos Mangalarga Marchador durante prova 
oficial de marcha. Ciência Veterinária nos Trópicos, 18(1): 52-57, 2015.

Smith, E.R.; Mason, M.M. Toxicology of the prostaglandins. Prostaglandins, 7(3): 247268, 1974.

Squires, E.L. Hormonal manipulation of the mare: a review. Journal of Equine Veterinary Science, 28(11): 627-634, 2008.

Taveiros, A.W.; Melo, P.R.M; Freitas Neto, L.M.; Aguiar Filho, C.R.; Silva, A.C.J.; Lima, P.F.; Oliveira, M.A.L. Produção de embriões de éguas Mangalarga Marchador utilizadas nas Regiões Nordeste e Sudeste do Brasil.
Medicina Veterinária (UFRPE), 2(3): 1924, 2008.

Taveiros, A.W.; Oliveira, M.A.; Lima, P.F.; Tenório, F.F.; Bartolomeu, C.C.; Santos, M. H.B.; Oliveira, L.R.; Iunes-Souza, T.C.; Freitas, J.C. Ultrasonographic monitoring of 103 recipient mares of different reproductive status during the first 30 days after embryo transfers. The Veterinary Record, 153(18): 558-560, 2003.

Weber, J.A.; Causey, R.C.; Emmans, E.E. Induction of luteolysis in mares by ultrasoundguided intraluteal treatment with PGF2alpha. Theriogenology, 55(9): 1769-1776, 2001. 